\author{
Research Article
}

\title{
HEPATOPROTECTIVE EFFECT OF PANCHA LAVANA DRAVAGAM AGAINST PARACETAMOL INDUCED HEPATOTOXICITY IN WISTAR ALBINO RATS - AN IN-VIVO STUDY
}

\section{G. Kaaruniya ${ }^{*}$, A. Mariappan², V. Suba ${ }^{3}$, R. Meenakumari4}

${ }^{*}$ PG Scholar, ${ }^{2}$ Lecturer, Department of Gunapadam, ${ }^{3}$ Assistant Professor, Department of Pharmacology, ${ }^{4}$ Director and Head of the Department, Department of Gunapadam, National Institute of Siddha, Chennai, India.

\begin{tabular}{l}
\hline Article info \\
\hline Article History: \\
Received: 08-09-2020 \\
Revised : 10-09-2020 \\
Accepted: 23-09-2021 \\
Published:16-10-2021 \\
\hline KEYWORDS: \\
Pancha Lavana \\
Dravagam, \\
Hepatoprotective \\
effect, \\
Paracetamol, \\
Siddha System.
\end{tabular}

\section{INTRODUCTION}

Siddha system is one of the traditional systems of medicine indigenous to Indian Sub-continent. This system was nursed by eminent Siddhars who lived at a very early period. They were men of highly cultured intellectuals and their formulations exhibit minute enumerations of morbid symptoms and it stood the test of time.[1]

\begin{tabular}{|c|c|}
\hline \multicolumn{2}{|c|}{ Access this article online } \\
\hline Quick Response Code & \\
\hline & https://doi.org/10.47070/ijapr.v9i9.1581 \\
\hline & $\begin{array}{l}\text { Published by Mahadev Publications } \\
\text { (Regd.) publication licensed under a } \\
\text { Creative Commons Attribution- } \\
\text { NonCommercial-ShareAlike } \\
\text { International (CC BY-NC-SA 4.0) }\end{array}$ \\
\hline
\end{tabular}

It uses herbs, metals, minerals and marine substances for preparation of medicines. Pancha Lavana Dravagam is one such poly mineral distillate formulation indicated for Gunmam (gastritis), Eri gunmam (dyspepsia), Soolai (colic), Kalleeral/ Maneeral Veekam (enlargement of liver or spleen), Soodhaga vali (dysmenorrhea), Soodhaga vaayu (amenorrhea).[2,3]

The liver is one of the largest organs in the body. It plays a central role in all metabolic processes in the body. In fat metabolism the liver cells break down fats and produce energy. In the metabolism of carbohydrates, the liver helps to ensure that the level of sugar in blood (blood glucose) stays constant. It also stores vitamins and minerals and releases them into the blood when needed. The liver also plays an important role in the metabolism of proteins: liver 
cells change amino acids in foods so that they can be used to produce energy or make carbohydrates or fats. Thus, maintaining the health of liver is very important to have a healthy life.[4]

Chronic liver disease occurs throughout the world irrespective of age, sex, region or race. Cirrhosis is an end result of a variety of liver diseases characterized by fibrosis and architectural distortion of the liver with the formation of regenerative nodules and can have varied clinical manifestations and complications. According to WHO, about $46 \%$ of global diseases and $59 \%$ of the mortality is because of chronic diseases and almost 35 million people in the world die of chronic diseases. Liver disease rates are steadily increasing over the years. According to National statistics in the UK, liver diseases have been ranked as the fifth most common cause of death. [5]

Chronic liver disease is marked by the gradual destruction of liver tissue over time. Liver diseases in this category include: Cirrhosis and Fibrosis of the liver. According to the National Institute of Diabetes and Digestive and Kidney Diseases (NIDDK), cirrhosis is the $12^{\text {th }}$ leading cause of death in the United States. ${ }^{6]}$

While thinking of treatment options for liver diseases, traditional healthcare system stands the frontline choice of treatment. Though in modern medicine, drugs obtained from herbal source rather than synthetic drugs are used in treating liver diseases. In Siddha classical literatures, many drugs have been mentioned for the protection and prevention of liver from chronic diseases. Hence, an attempt was made to evaluate the liver protection activity of a poly mineral distillate formulation Pancha Lavana Dravagam (PLD) through the paracetamol induced hepatotoxicity in wistar albino rat models.

\section{MATERIALS AND METHODS}

Ingredients of PLD

- Purified Vediyuppu (Potassium nitrate)

- Purified Kariyuppu (Sodium chloride)

- Purified Padigaram (Aluminum potassium sulfate)

- Purified Vengaram (Borax)

- Purified Navacharam (Ammonium chloride)

Figure 1 : Ingredients of Pancha Lavana Dravagam

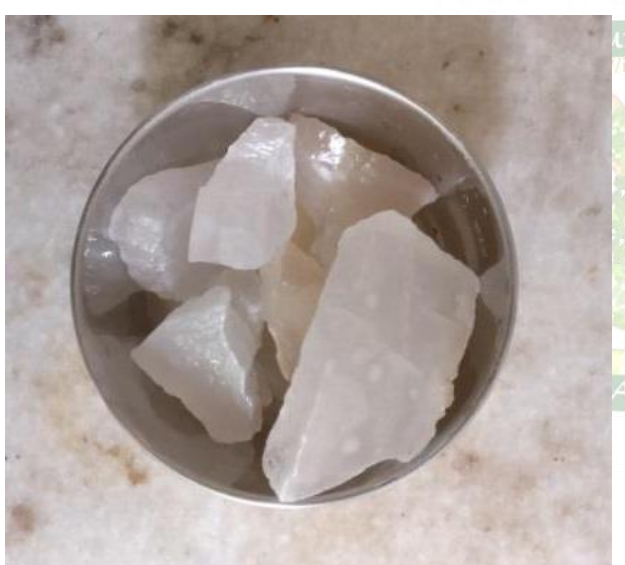

Unpurified Navacharam

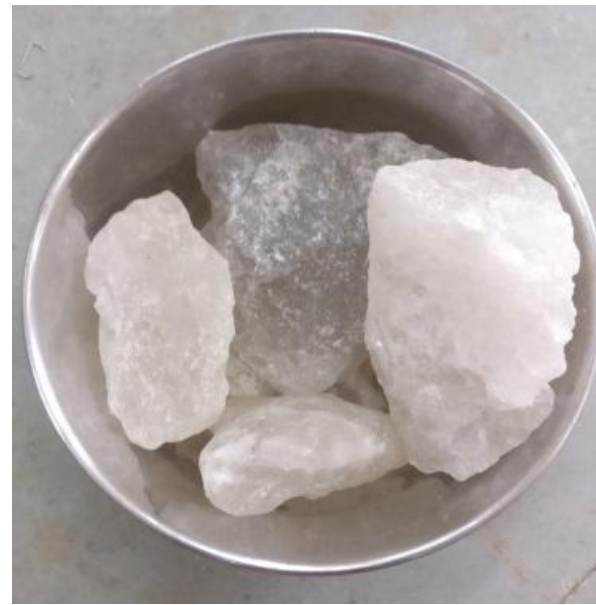

Unpurified Padigaram

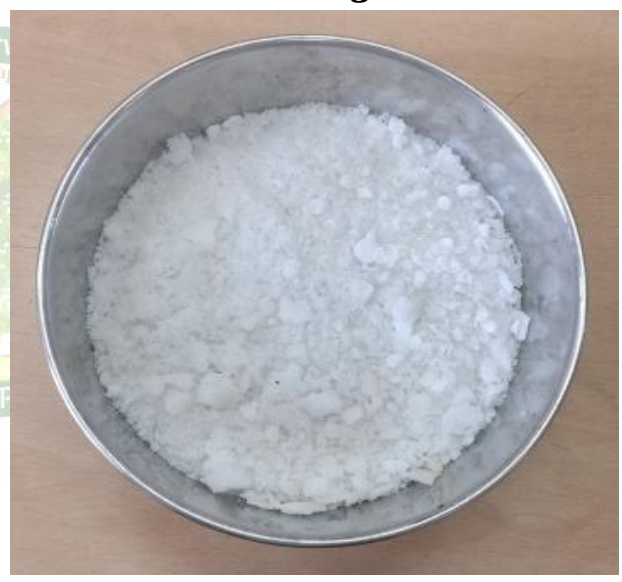

Purified Navacharam

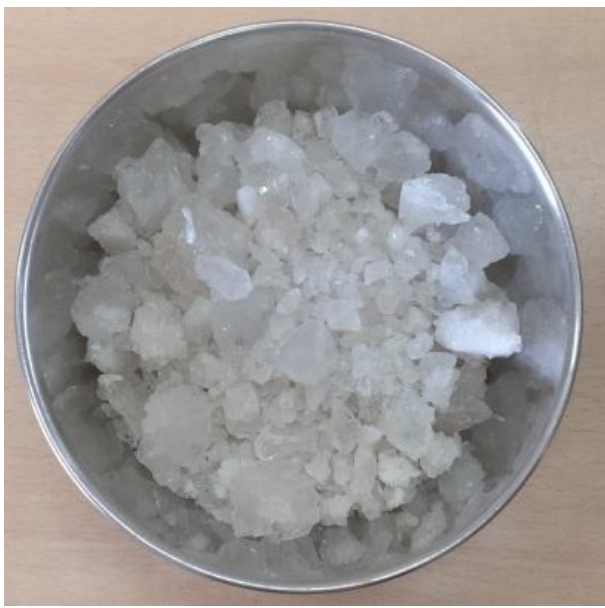

Purified Padigaram 


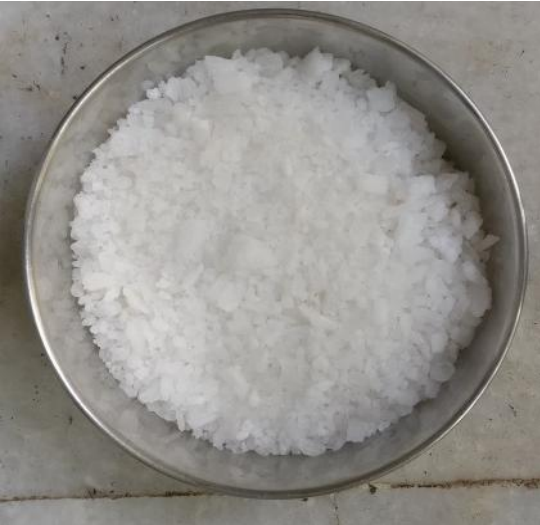

Unpurified Vediyuppu

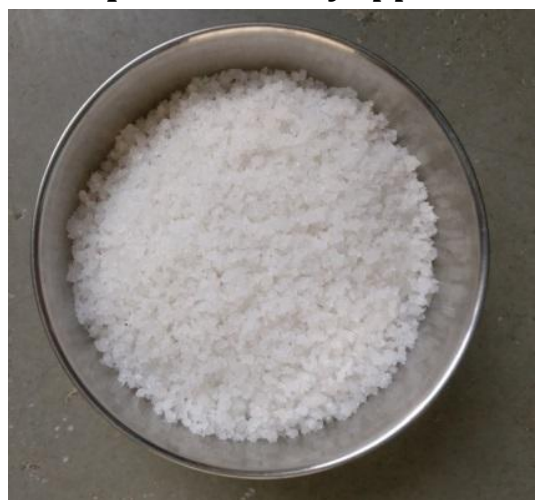

Unpurified Kariyuppu

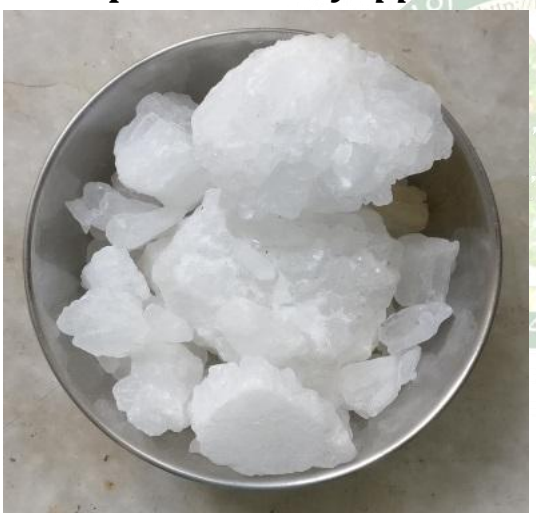

Unpurified Vengaram

Preparation of Test drug PLD

The test drug Pancha Lavana Dravagam (PLD) was prepared by distillation using traditional distillation apparatus called "Dravaga Vaalai Iyanthitam". The ingredients of PLD include Vediyuppu (Potassium nitrate), Vengaram (Borax), Kariyuppu (Sodium chloride), Navacharam (Ammonium chloride) and Padigaram (Aluminium potassium sulfate). 600 grams of Vediyuppu, Kariyuppu, Padigaram and 300 grams of Vengaram, Navacharam was taken and subjected to series of purification processes as mentioned in Siddha literatures before preparing the medicine. Then all the salts were powdered and placed in the large pot of Dravaga Vaalai Iyanthiram..$^{[2]}$ Then the mouth of the pot was closed with suitable cupular distillation set and covered with muddy cloth and allowed to dry. When the pot was heated, the upper cupular part of the distillation set was filled with cold water and closed. Whenever the water becomes hot,

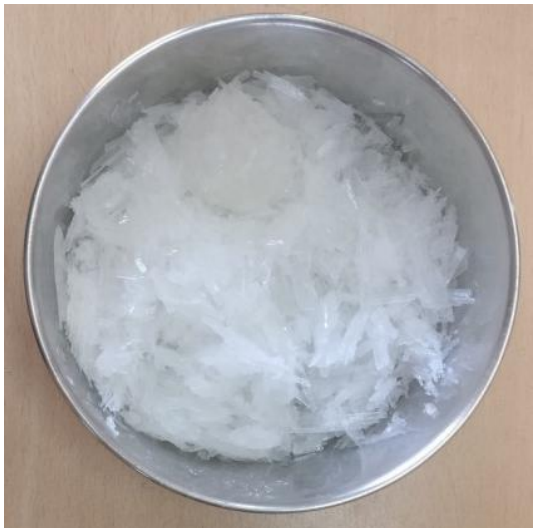

\section{Purified Vediyuppu}

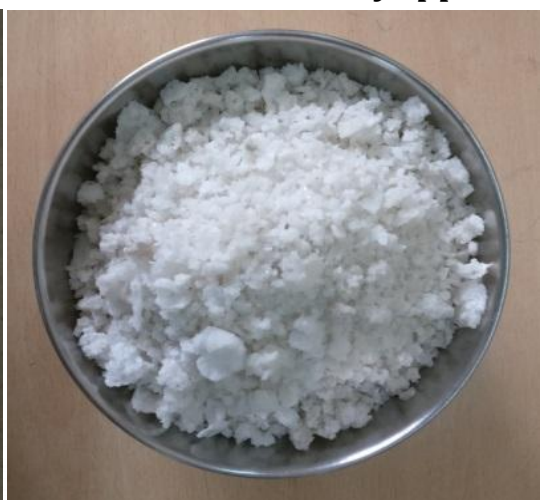

Purified Kariyuppu

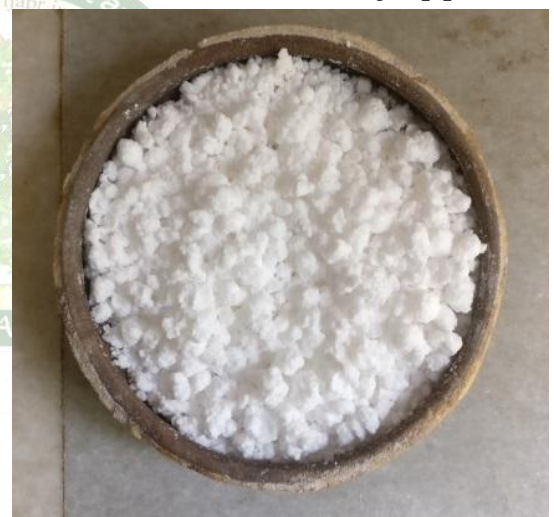

Purified Vengaram

the water was removed and replaced by fresh cold water. When the pot was heated, the steam evolving from the salt ingredients were condensed as liquid drops through the inner tube of the distillation set. This was collected in a glass bottle and stored. ${ }^{77,8]}$

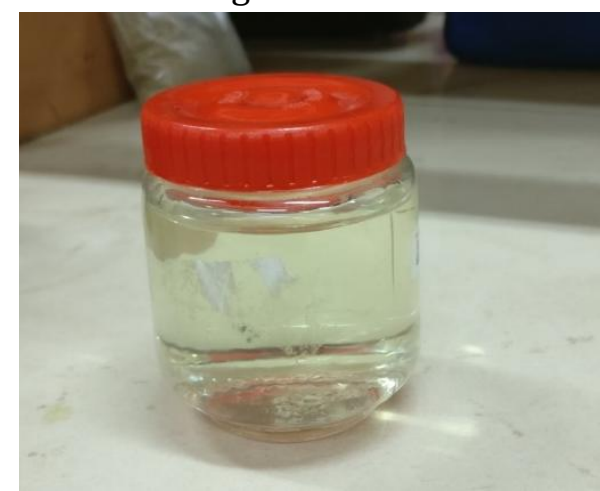

Figure 2 : Pancha Lavana Dravagam 


\section{Chemicals and Drugs Used}

All the materials required for the experiment were of analytical grade. Silymarin and Paracetamol tablets were procured from Smith stocking and co, Chennai. Diagnostic kits manufactured by Ranbaxy Diagnostics Ltd., New Delhi, India were used for the estimation of SGOT, SGPT, ALP, Total Bilirubin and Total Proteins.

\section{Experimental Animals}

The study was carried out using Wistar Albino strain healthy rats (Rattus norvegicus) of both sexes weighing 150 to $200 \mathrm{gm}$. The animals were procured from Tamil Nadu Veterinary and Animal sciences University, Madhavaram milk colony, Chennai-51, Tamil Nadu, India. These animals were accommodated at the Animal house, National Institute of Siddha at standard environment with controlled temperature of $22^{\circ} \mathrm{C} \pm 3^{\circ} \mathrm{C}$ and relative humidity between $55 \% \pm 5 \%$ with a 12-12h light-dark cycle. The animals were provided with standard pellet food (VRK Nutritional Solutions, Maharastra) and water ad libidum during the entire study period. The animals were acclimatized for 7 days prior to the study period.

All the experiment protocols employed herein was approved by Institutional Animal Ethical Committee of National Institute of Siddha, Chennai-47, Tamil Nadu, India. (NIS/IAEC-VII/28082018/04 dated 28.08.2018) and conducted in accordance with the guidelines established by Committee for the Purpose of Control and Supervision of Experiments on Animals (CPCSEA) for laboratory animal facilities.

\section{Dose Calculation}

The human therapeutic dose of PLD is 5 to 15 drops i.e., $0.75 \mathrm{ml}$. The animal effective dose was arrived using body surface area ratio by Paget and Barnes, 1964.

\section{Paracetamol-induced Hepatotoxicity}

Paracetamol (acetaminophen) is one of the most frequently used drugs for its analgesic and antipyretic properties. It is safe and effective at recommended doses, whereas overdose may lead to hepatotoxicity and acute liver failure. In fact, paracetamol induced hepatotoxicity remains the most common cause of acute liver failure in many countries.[15]

\section{Hepatoprotective Studies}

Wistar albino rats of both sexes were divided into five groups of six animals each and were given the following treatment orally for seven days. Group I served as a Normal control which received only the water. Group II served as the toxicant control and it received Paracetamol at a dose of $1 \mathrm{gm} / \mathrm{kg}$ bw, p.o. Groups III and IV served as a test group which received PLD at doses $1 \mathrm{ml} / \mathrm{kg}$ and $2 \mathrm{ml} / \mathrm{kg}$ bw, p.o. with paracetamol $1 \mathrm{gm} / \mathrm{kg}$ bw, p.o. Group $\mathrm{V}$ served as standard group receiving Silymarin $50 \mathrm{mg} / \mathrm{kg}$ bw, p.o. and paracetamol $1 \mathrm{gm} / \mathrm{kg}$ bw, p.o.

After $24 \mathrm{~h}$ of the last treatment, blood sample was collected individually for all the animals from the retro-orbital plexus, allowed to clot for 1 hour at room temperature and serum was separated by centrifugation at $2500 \mathrm{rpm}$ at $30^{\circ} \mathrm{C}$ for $15 \mathrm{~min}$. the serum thus collected was analyzed for various parameters.[9]

\section{Assessment of Liver Function}

The serum obtained after centrifugation was analyzed for various biochemical parameters like SGOT/AST, SGPT/ALT, ALP, Total Bilirubin and Total Proteins. Rietman and Frankel method was used to measure the serum transaminase activity.[10] Scand method was used to determine ALP and serum bilirubin. ${ }^{[11]}$ Lowry $\mathrm{OH}$, et al was used to measure total proteins level.[12]

\section{Histopathological Studies}

The animals were sacrificed by over dose of thiopental sodium and the abdomen was cut open to remove the liver, observed for any visible changes through the naked eyes. Then the liver tissue was quickly removed, cleaned with saline and fixed in $10 \%$ neutral formalin solution. Initially the materials were fixed in $10 \%$ buffered neutral formalin and then with Bouin solution (mixture of $75 \mathrm{ml}$ of saturated picric acid, $25 \mathrm{ml}$ of $40 \%$ formaldehyde and $5 \mathrm{ml}$ of glacial acetic acid) for 12 hours, then embedded in paraffin and cut into $5-6 \mu \mathrm{m}$ thick section and stained using hematoxylin-eosin dye and finally mounted in diphenyl-xylene. They were then observed under light microscope (100x) for histopathological changes in liver architecture and their photomicrographs were taken for evaluation.

\section{Statistical Analysis}

The experimental results were expressed as the Mean \pm SEM for animals in each group. The biochemical parameters were analyzed statistically using one-way analysis of variance ANOVA, followed by Dunnett's multiple comparison tests using Graph pad INSTAT 3 software. $P$ value of $<0.05$ was considered as statistically significant.

\section{RESULTS}

\section{Effect of PLD on Biochemical evaluation}

Table 1 and 2 shows the activities of serum cytosolic enzymes SGOT, SGPT, ALP and Total Bilirubin. They were increased significantly $(P<0.001)$ in the toxicant group when compared to the control group. On the other hand, there was significant $(P<0.001)$ decrease in total protein levels of the toxicant group when compared to the control group due to the hepatic damage caused by paracetamol. Test group treated with PLD at $1 \mathrm{ml} / \mathrm{kg}$ bw showed a significant reduction in SGOT $(P<0.01)$ and ALP 
$(\mathrm{P}<0.01)$ when compared to the toxicant control group. Test group treated with PLD at $2 \mathrm{ml} / \mathrm{kg}$ bw showed a significant reduction in SGOT $(\mathrm{P}<0.001)$, SGPT $(\mathrm{P}<0.01)$, ALP $(\mathrm{P}<0.001)$ and Total Bilirubin $(\mathrm{P}<0.01)$ when compared to the toxicant control group. There was also significant $(\mathrm{P}<0.001)$ increase in the Total protein levels of the test drug PLD $2 \mathrm{ml} / \mathrm{kg}$ bw treated groups when compared to the toxicant group. These results are comparable with that of the standard drug $(\mathrm{P}<0.001)$

Table 1: Effect of Pancha Lavana Dravagam (PLD) on SGOT, SGPT and ALP in paracetamol induced hepatotoxic rats

\begin{tabular}{|c|l|l|l|l|}
\hline Groups & Treatment/ Dose (p.o) & SGOT/AST (IU/L) & SGPT/ALT (IU/L) & ALP (IU/L) \\
\hline I. & Control Group (Water) & $64.13 \pm 4.16$ & $28.36 \pm 2.08$ & $101.91 \pm 7.09$ \\
\hline II. & Paracetamol (1gm/kg) & $156.5 \pm 9.26 \mathrm{a}^{* *}$ & $90.33 \pm 6.83 \mathrm{a}^{* * *}$ & $134.16 \pm 8.63 \mathrm{a}^{* * *}$ \\
\hline III. & PLD (1ml/kg) & $137.33 \pm 10.55 \mathrm{~b}^{* *}$ & $86.0 \pm 4.33$ & $114.0 \pm 8.64 \mathrm{~b}^{* *}$ \\
\hline IV. & PLD $(2 \mathrm{ml} / \mathrm{kg})$ & $122.83 \pm 6.30 \mathrm{~b}^{* * *}$ & $76.33 \pm 5.53 \mathrm{~b}^{* *}$ & $98.5 \pm 7.50 \mathrm{~b}^{* * *}$ \\
\hline V. & Silymarin $(50 \mathrm{mg} / \mathrm{kg})$ & $102.83 \pm 9.23 \mathrm{~b}^{* * *}$ & $49.0 \pm 6.0 \mathrm{~b}^{* * *}$ & $81.5 \pm 6.86 \mathrm{~b}^{* * *}$ \\
\hline
\end{tabular}

Values are Mean \pm Standard deviation $(\mathrm{n}=6) .{ }^{*} \mathrm{P}<0.05 ;{ }^{* *} \mathrm{P}<0.01 ;{ }^{* * *} \mathrm{P}<0.001$ against toxicant control. acomparison made between control and paracetamol group; b- comparison was made between paracetamol group and test drug treated groups.

Table 2: Effect of Pancha Lavana Dravagam (PLD) on Total Bilirubin and Total Protein in paracetamol induced hepatotoxic rats

\begin{tabular}{|c|l|l|l|}
\hline Groups & Treatment/ Dose (p.o) & TB (mg/dl) & TP (mg/dl) \\
\hline I. & Control Group (Water) & $0.36 \pm 0.08$ & $6.4 \pm 0.69$ \\
\hline II. & Paracetamol (1gm/kg) & $0.78 \pm 0.11 \mathrm{a}^{* * *}$ & $2.41 \pm 0.50 \mathrm{a}^{* * *}$ \\
\hline III. & PLD $(1 \mathrm{ml} / \mathrm{kg})$ & $0.63 \pm 0.13$ & $3.0 \pm 0.34 \mathrm{~b}^{*}$ \\
\hline IV. & PLD $(2 \mathrm{ml} / \mathrm{kg} \mathrm{bw)}$ & $0.53 \pm 0.10 \mathrm{~b}^{* *}$ & $3.65 \pm 0.32 \mathrm{~b}^{* * *}$ \\
\hline V. & Silymarin $(50 \mathrm{mg} / \mathrm{kg} \mathrm{bw})$ & $0.46 \pm 0.12 \mathrm{~b}^{* * *}$ & $4.18 \pm 0.38 \mathrm{~b}^{* * *}$ \\
\hline
\end{tabular}

Values are Mean \pm Standard deviation $(\mathrm{n}=6)$. ${ }^{*} \mathrm{P}<0.05 ;{ }^{* *} \mathrm{P}<0.01 ;{ }^{* * *} \mathrm{P}<0.001$ against toxicant control. acomparison made between control and paracetamol group; b- comparison was made between paracetamol group and test drug treated groups.

\section{Effect of PLD on Histopathological Evaluation}

On the histopathological evaluation of Pancha Lavana Dravagam depicted in Figure 3, marginal changes near portal vein with migration of inflammatory cells and extensive periportal degenerative changes were observed. In test drug treated group, there was rare appearance of Kupffer cells with no evidence of phagocytosis in intra cytoplasmic region and no signs of nodular degeneration and cirrhosis was noted. In standard treated group, centrilobular zone appears normal with stable network of hepatocytes and there was no evidence of mesenchymal reaction on to the hepatic parenchyma.

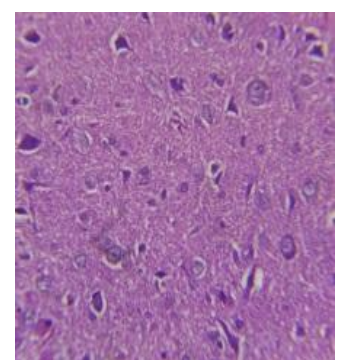

A

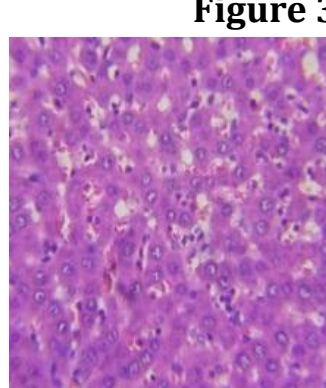

B

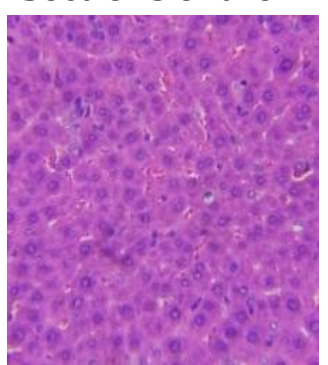

C

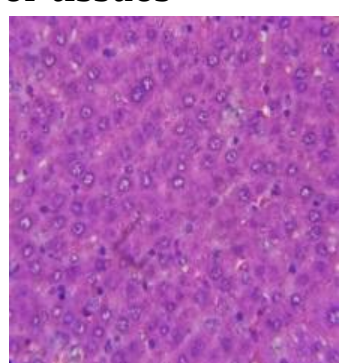

D

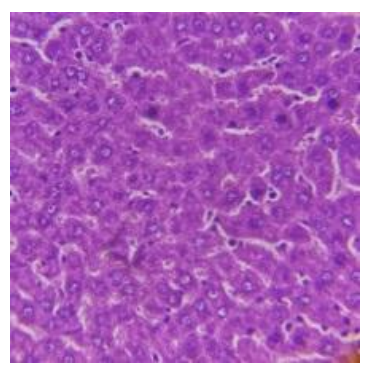

$\mathbf{E}$

Where

A - Control; B - Toxicant control Paracetamol (1gm/kg); C - Test dose PLD 1 (1ml/kg);

D - Test dose PLD $2(2 \mathrm{ml} / \mathrm{kg})$ and $\mathbf{E}$ - Standard silymarin $(50 \mathrm{mg} / \mathrm{kg})$ respectively. Liver sections were stained with hematoxylin and eosin $(100 \times)$. 


\section{DISCUSSION}

In Siddha system, the liver is known by various names like Eeral, Kaleeral, Valapaateeral, etc.[13] The liver disorders are given with the synonyms like Valapaateeral Noi, Maandha Katti, Kal maandham and Yakudham. ${ }^{[14]}$ In Siddha classical literatures, there have been many herbals and minerals are mentioned for the maintenance of liver health. In modern medical science, there has been no specific treatment for chronic liver diseases and drugs only treat it symptomatically. But in Siddha system of medicine, many drugs and therapies were described by Siddhars for treating liver diseases by pacifying the vitiated Pitha humor in normal body. One such poly mineral formulation is Pancha Lavana Dravagam, which is a distillate of five minerals or salts which implies the five elements of nature.

Paracetamol is metabolized in the liver by Phase II conjugating enzymes mainly, UDPglucuronosyl transferase (UGT) and sulfotransferase (SULT), converting it to nontoxic compounds which are then excreted with the urine. The remaining paracetamol, approximately $5-9 \%$ is metabolized by the cytochrome P450 enzymes (CYPs), mainly CYP 2E1 into the highly reactive intermediate metabolite $\mathrm{N}$ acetyl-p-benzoquinone imine (NAPQI). Generally, NAPQI is rapidly detoxified by conjugating with glutathione (GSH). However, when phase II metabolizing enzymes are saturated after APAP overdose, excessive NAPQI deplete GSH, leading to covalent binding of sulfhydryl groups in cellular proteins, especially mitochondrial proteins. This results in mitochondrial oxidative stress and dysfunction, ultimately hepatocytes necrosis.[15]

In the present study, elevated levels of SGOT, SGPT, ALP and Total Bilirubin confirmed the paracetamol induced liver damage. The reactive oxygen species generation and lipid peroxidation of cell membranes leads to loss of membrane integrity, changes in membrane potential and an increase in membrane permeability, which in turn results in leakage of the enzymes from liver cells into circulation resulting in increased serum levels.[16] On treatment with PLD, there was a reduction in serum enzyme levels which may be due to the reduction in the oxidative stress produced by paracetamol intoxication.

This reduction of oxidative stress may be attributed to the anti-oxidant property of Padigaram (Aluminium Potassium Sulfate), Vengaram (Borax) which reduces lipid peroxidation and enhances the anti-oxidant defense mechanism.[17] The sodium and potassium present in Kariyuppu (Sodium chloride) and Vediyuppu (Potassium nitrate) helps in the transport of amino acids within the cell which may be helpful in transport of cysteine, glutamate and glycine responsible for the formation of glutathione.
Due to the parenchymal damage of hepatic cells, there was a decrease in total protein levels of paracetamol treated groups. Pancha Lavana Dravagam may facilitate the regeneration of parenchyma of hepatic cells resulting in the significant increase of total protein levels in PLD treated groups.

\section{CONCLUSION}

The test drug PLD demonstrated potent liver protective effects against paracetamol induced hepatotoxicity in rats, which might be related to the decrease in oxidative stress, lipid peroxidation, and ROS generation.

\section{ACKNOWLEDGMENTS}

The authors are thankful to The Tamil Nadu DR. M.G.R. Medical University and National Institute of Siddha for providing necessary laboratory facilities to carry out the research work.

\section{REFERENCES}

1. T. V. Sambasivam Pillai; Introduction to Siddha Medicine, Directorate of Indian Medicine and Homeopathy; $1^{\text {st }}$ ed, 1993.

2. Dr. S. Chidambarathanu Pillai; Siddha System of Pharmacopoeia, $1^{\text {st }}$ ed, 1992.

3. T. V. Sambasivam pillai, Tamil-English Dictionary, Department of Indian medicine and Homeopathy; $2^{\text {nd }}$ ed, 1998.

4. informedHealth.org [Internet]. Cologne, Germany: Institue for Quality and Efficiency in Health Care (IQWiG); 2006-. How does the liver work? 2009 Sep 17 [Updated 2016 Aug 22].Available from: https://www.ncbi.nlm.nih.gov/books/NBK279393

5. Global burden of liver diseases: A true burden on Health Sciences and Economics; World Gastroenterology Association. Available from: https://www.worldgastroenterology.org/publicati ons/e-wgn/e-wgn-expert-point-of-view-articlescollection/global-burden-of-liver-disease-a-trueburden-on-health-sciences-and-economies.

6. Stanfordhealthcare.org [Internet]. California, United States. Chronic liver diseases. Available from: https://stanfordhealthcare.org/medicalconditions/liver-kidneys-and-urinarysystem/chronic-liver-disease.html

7. Dr. Anaivari Anandan; Dr. M. Thulasimani; Siddha Materia Medica, Directorate of Indian Medicine and Homeopathy; $1^{\text {st }}$ ed, 2008.

8. Formulary of Siddha Medicines; The Indian Medical Practitioners Co-Operative Pharmacy and Stores Ltd.; $3^{\text {rd }}$ ed, 1989.

9. P Madhu Kiran, A Vijaya Raju, B Ganga Rao; Investigation of hepatoprotectivity of Cyathea gigantean (Wall ex Hook) leaves against 
paracetamol induced hepatotoxicity in rats; Asian Pacj of Trop Biomed; 2012; 2(5); 352-356.

10. Reitman S, Frankel AS. A colorimetric method for the determination of serum glutamic oxloacetic and glutamic pyruvic transaminases. Am J Clin Pathol 1957; 28: 56-63.

11. Keiding R, Horder M, W Gerhardt Denmark, Pitkänen E, Tenhunen R, Strömme JH, et al. The committee on enzymes of the scandinavian society for clinical chemistry and clinical physiology: Recommended methods for the determination of four enzymes in blood. Scand J Clin Lab Invest. 1974; 33: 291-306.

12. Lowry OH, Rosebrough NJ, Farr AL, Randall RJ.J Biol Chem. 1951; 193: 265-283.

13. Dr. R. Thiyagarajan. Udar Kooru. Directorate of Indian Medicine and Homeopathy.1992.
14. Dr.Na.Kuppusamy Mudhaliyar. Siddha Maruthuvam (Podhu). Directorate of Indian Medicine and Homeopathy.2004.

15. Mingzhu yan, Yazhen huo, Shutao yin, Hongbo Hu. Mechanisms of acetaminophen-induced liver injury and its implications for therapeutic interventions. Redox biology 2018; 17: 274-283.

16. Rahman MM, Lee SJ, Mun AR, Adam GO, Park RM, Kim GB, et al. Relationships between blood $\mathrm{Mg}^{2+}$ and energy metabolites/enzymes after acute exhaustive swimming exercises in rats. Biol Trace Elem Res 2014; 161(1): 85-90.

17. Sinan I, Ismail K, Ibrahim HC, A. Fatih F. The effects of dietary boric acid and borax supplementation on lipid peroxidation, antioxidant activity and DNA damage in rats. J Trace Elem Med Biol 2010; 24(3): 161-164.

\section{Cite this article as:}

G.Kaaruniya, A.Mariappan, V.Suba, R.Meenakumari. Hepatoprotective Effect of Pancha Lavana Dravagam against Paracetamol induced Hepatotoxicity in Wistar Albino Rats- An In-Vivo Study. International Journal of Ayurveda and Pharma Research. 2021;9(9):1-7. https://doi.org/10.47070/ijapr.v9i9.1581

Source of support: Nil, Conflict of interest: None Declared

\section{*Address for correspondence} Dr G. Kaaruniya

PG Scholar,

Department of Gunapadam,

National Institute of Siddha,

Chennai.

Email: kaarukicha@gmail.com

Disclaimer: IJAPR is solely owned by Mahadev Publications - dedicated to publish quality research, while every effort has been taken to verify the accuracy of the content published in our Journal. IJAPR cannot accept any responsibility or liability for the articles content which are published. The views expressed in articles by our contributing authors are not necessarily those of IJAPR editor or editorial board members. 